\title{
Diagnóstico de áreas contaminadas pela disposição final de resíduos sólidos no município de Paço do Lumiar (MA)
}

\author{
Diagnosis of contaminated areas by final disposal of \\ solid waste in the municipality of Paço do Lumiar (MA), Brazil
}

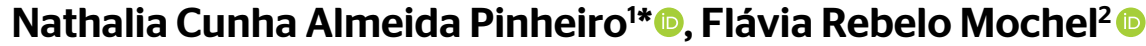

口

\begin{abstract}
RESUMO
A disposição final de resíduos sólidos é considerada uma fonte potencial de contaminação e tem merecido destaque em função dos problemas ambientais e socioeconômicos que pode gerar. O município de Paço do Lumiar, no Maranhão, utiliza um lixão como forma de disposição de resíduos sólidos urbanos mesmo após ter cessado o prazo para o fim dos lixões no Brasil conforme a Política Nacional de Resíduos Sólidos, Lei Federal no 12.305 , de 2 de agosto de 2010. Em virtude disso, este estudo teve como objetivo detectar áreas contaminadas pela disposição de resíduos sólidos em Paço do Lumiar com base na metodologia do Manual de Gerenciamento de Áreas Contaminadas do projeto CETESB/GTZ (1999), utilizando os compartimentos ambientais solo e água superficial como objetos de análise. Assim, verificouse que o lixão tem contribuído para a contaminação do solo com metais pesados no local de disposição e a 200 m a sua jusante, o que pode significar contaminação potencial da água subterrânea em virtude de a geologia local e o solo arenoso serem facilitadores no processo de transporte de contaminantes. Já a análise da água superficial revelou que a disposição de resíduos sólidos pode estar contribuindo menos que outras fontes de contaminação, destacando-se, nesse contexto, os efluentes gerados pelas comunidades que ocupam a bacia. Portanto, como a contaminação verificada compromete alguns usos da terra (residencial e agrícola), estudos posteriores poderão contemplar o processo de remediação de áreas contaminadas conforme material da CETESB/GTZ (1999) para que medidas corretivas minimizem os impactos ambientais na região.
\end{abstract}

Palavras-chave: resíduos sólidos; disposição final; contaminação; lixão.

\begin{abstract}
The final disposal of solid waste is considered a potential source of contamination and has been highlighted due to the environmental problems and socioeconomic factors that it can generate. The municipality of Paço do Lumiar, Maranhão, uses a garbage dump as a way of disposing urban solid waste, even after the deadline for the end of dumps in Brazil, as established by the National Solid Waste Policy, Federal Law No. 12,305, dated August 2, 2010. As a result, the objective of this study was to detect areas contaminated by disposal of solid waste in Paço do Lumiar, based on the Workshop Management of Contaminated Areas' methodology, a part of the project CETESB/GTZ (1999), using the environmental compartments soil and surface water as objects of analysis. Thus, it was found that the garbage dump has contributed to the contamination of soil with heavy metals in the place of provision and 200m to its downstream, which can mean potential contamination of ground water due to the local geology and the fact that sandy soil facilitates the process of transporting contaminants. The analysis of the surface water revealed that the disposal of solid waste can contribute less than other sources of contamination, highlighting in this context those generated by the communities that occupy the basin. Therefore, as the verified contamination compromises some land uses (residential and agricultural), further studies may contemplate the remediation process of these contaminated areas according to the CTESB/ GTZ (1999) material for stablishing measures to minimize this region's environmental impacts.
\end{abstract}

Keywords: solid waste; final disposition; contamination; dump. gerando passivo ambiental em decorrência da falta ou da ineficiência de sua gestão. Em virtude disso, no fim do século XX e início do XXI, a gestão e o manejo de resíduos sólidos passaram
As práticas de desenvolvimento atuais associadas ao intenso consumismo têm levado ao aumento na produção de resíduos sólidos, 
a ser debatidos pela sociedade mais intensamente (RIBEIRO \& MORELLI, 2009).

A disposição de resíduos sólidos de forma inadequada tem provocado a contaminação de mananciais superficiais e subterrâneos, ampliando problemas e gerando gastos de recursos (GUERRA \& CUNHA, 2005). Isso porque, no local de disposição de resíduos sólidos, o balanço hídrico ocorre com a entrada de água por meio da precipitação e de processos de decomposição de resíduos sólidos; as perdas de água ocorrem através da evaporação, transpiração, difusão lateral na cobertura do aterro e produção de lixiviados (chorume). O chorume gerado na decomposição de resíduos sólidos possui características física, química e biológica que podem comprometer a qualidade ambiental (LISK, 1991).

As atividades de disposição final de resíduos sólidos devem ser consideradas como fontes potenciais de contaminação (BRASIL, 1981), mesmo aquelas em que tenham sido implantadas medidas de segurança à unidade. No Brasil, os danos ambientais em virtude da disposição inadequada de resíduos sólidos ainda são muito comuns. A Pesquisa Nacional de Saneamento Básico (2008), promovida pelo Instituto Brasileiro de Geografia e Estatística (IBGE), revelou que mais de 70\% dos municípios brasileiros faziam disposição dos seus resíduos sólidos em lixões e aterros controlados até o ano de 2008. Na Região Nordeste, os Estados do Piauí, do Maranhão e de Alagoas são os que possuem mais municípios dispondo seus resíduos nos chamados lixões (IBGE, 2010b).

O município de Paço do Lumiar, localizado na Região Metropolitana da Grande São Luís (MA), dispõe seus resíduos sólidos em lixão desde o ano de 2005 (SNIS, 2006). Isso tem gerado a insatisfação da população, principalmente de pescadores e de agricultores, pois estes sentem que suas atividades são prejudicadas pela poluição causada por esse lixão. Em função disso, este trabalho objetivou detectar áreas contaminadas em decorrência da atividade de disposição final de resíduos sólidos em Paço do Lumiar, para analisar se o lixão pode interferir na contaminação do solo e dos recursos hídricos locais e, consequentemente, nas atividades dos moradores do seu entorno.

\section{METODOLOGIA}

O município de Paço do Lumiar está localizado no Golfão Maranhense, na porção norte da Ilha do Maranhão, a 2³0'S e 447’O (FEITOSA \& TROVÃO, 2006). A sua área territorial corresponde a $122,828 \mathrm{~km}^{2}$, com população de 105.121 habitantes, dos quais $75 \%$ vivem no meio urbano (IBGE, 2010a). O clima do município, segundo a classificação de Köppen, é do tipo Aw, tropical chuvoso, com predominância de chuvas nos meses de janeiro a abril e temperatura média anual oscilando em torno de $28^{\circ} \mathrm{C}$ (ARAÚJO; TELES; LAGO, 2009). Em relação ao aspecto florístico, o IBGE (2002) destaca que o município possui formações pioneiras com influência fluviomarinha (manguezal) e floresta ombrófila aberta bastante antropizada com áreas ocupadas por vegetação secundária e pela agropecuária (IBGE, 2002).

Dentre as unidades geológicas da Ilha do Maranhão (formações Açuí, Barreiras e Itapecuru), a formação Barreiras é predominante no município de Paço do Lumiar (PEREIRA et al., 2004). A litologia da formação Barreiras é constituída, a partir da base, por arenitos inconsolidados, vermelhos e amarelados, siltitos amarelados a ocre e argilitos caolínicos. Nos clásticos, há ocorrência de conglomerados de matacões e blocos de arenito médio a grosso, quartzoso, ferruginizado. No topo, ocorrem areias brancas quartzosas (SOUSA, 2000; PEREIRA et al., 2004). Já em relação ao solo, é predominante no município de Paço do Lumiar o tipo latossolo vermelho-amarelo (MARANHÃO, 1991).

O local de disposição de resíduos sólidos de Paço do Lumiar está localizado na zona rural desse município a 2²9’6,14”S e 446 $48,91^{\prime \prime O}$ (Datum: SIRGAS2000), na bacia do Rio Paciência, próximo ao seu estuário (PAÇO DO LUMIAR, 2006). No seu entorno, há duas comunidades, Pindoba e Iguaíba, que se destacam pela atividade de agricultura e pesca. No raio de $2 \mathrm{~km}$ do entorno do lixão de Paço do Lumiar, há oito unidades de paisagem distintas, destacando-se áreas urbanizadas, corpos d'água estuarinos, mangue, mata ciliar, capoeira de terra firme, áreas utilizadas para agricultura/pecuária, solo exposto, além da extensão do próprio lixão. Já no raio de 1 km em relação à área do lixão, há todas as paisagens descritas acima, exceto área urbanizada (Figura 1).

Em relação ao aspecto topográfico da região, o lixão fica em cota mais elevada em comparação aos corpos hídricos locais. Pelas cotas altimétricas das curvas de nível, induz-se que o lixão pode contribuir para a contaminação dos compartimentos ambientais ao norte, incluindo o igarapé do Tiririca (Figura 2).

\section{Procedimentos metodológicos}

A metodologia de avaliação ambiental descrita pelo Manual de Gerenciamento de Áreas Contaminadas, do projeto CETESB/GTZ (1999), foi utilizada para identificar áreas contaminadas pela atividade de disposição final de resíduos sólidos no município de Paço do Lumiar. Portanto, seguiram-se as etapas, de maneira sistemática, denominadas Definição da região de interesse, Identificação de áreas potencialmente contaminadas (AP), Avaliação preliminar e Investigação confirmatória. As três primeiras fases foram fundamentais para serem definidos os pontos de coleta de água e de solo para a etapa de Investigação confirmatória.

Os pontos de solo amostrados obedeceram ao eixo sentido sul-norte em virtude da topografia local do terreno, que tem uma queda de cota nessa perspectiva. Assim, para amostragem do solo, foram escolhidos seis pontos, sendo um deles na lateral da própria célula utilizada para disposição de resíduos sólidos e que foi denominado ponto P03-S (Figura 3). 


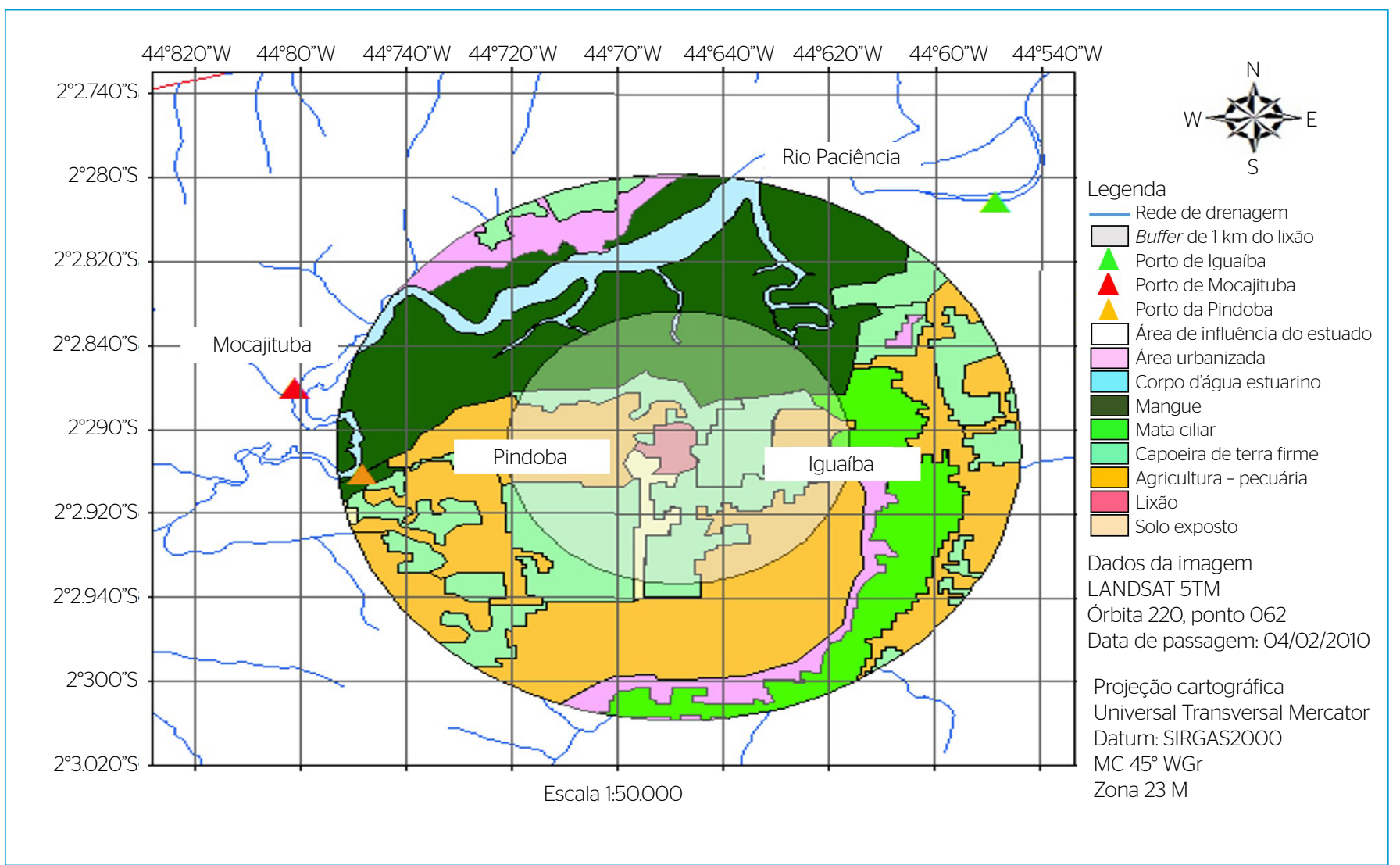

Figura 1 - Mapa de uso do solo da área de entorno do lixão no município de Paço do Lumiar (MA) em raio de 2 km, destacando-se as áreas de influência no raio de $1 \mathrm{~km}$ da disposição de resíduos sólidos.

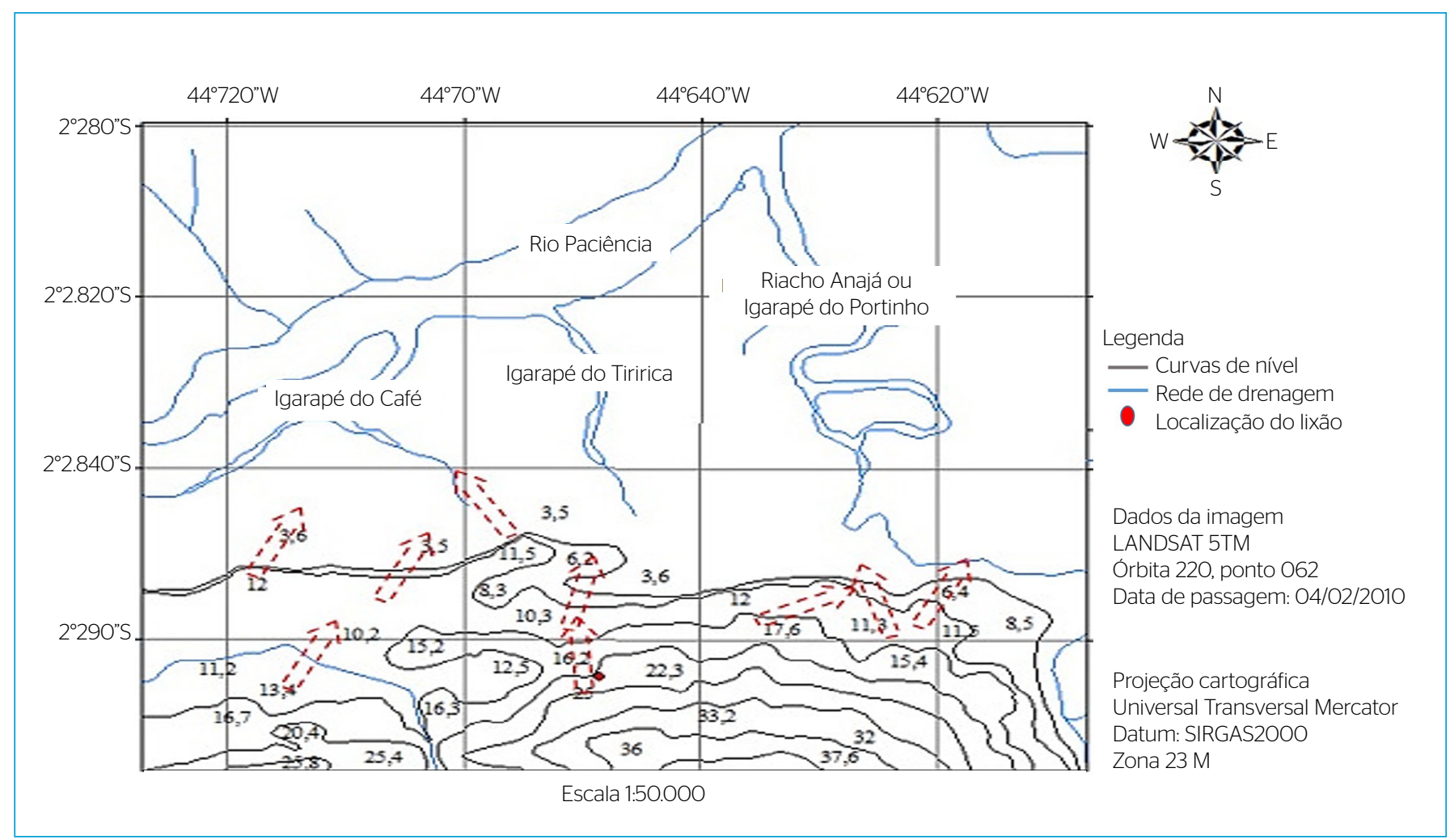

Figura 2 - Demonstrativo evidenciando o escoamento superficial da água, por meio das setas vermelhas, com base em curvas de nível. 
Os pontos de amostragem foram escolhidos com base no P03-S, exceto o ponto controle (P06-S), localizado a $3 \mathrm{~km}$ de distância do lixão, em área ocupada por vegetação secundária e próxima a residências (Tabela 1).

Para análise de solo, foram feitas amostragens simples e superficiais (0-30 cm), levando-se em consideração o critério indicado pela norma ISO/DIS 10381-1 (CETESB/GTZ, 1999). O procedimento de coleta de amostras foi realizado de acordo com Byrnes (1994), USEPA (1989; 1991) e Sabbag (2013). Os parâmetros físicos e químicos avaliados para o solo foram permeabilidade, densidade, umidade, granulometria, teor de matéria orgânica, $\mathrm{pH}$, fósforo, potássio, cálcio, magnésio, alumínio, saturação de bases, $\mathrm{H}+\mathrm{Al}$, capacidade de troca catiônica, boro, cobre, ferro, manganês, zinco, mercúrio, chumbo, níquel e cádmio. A técnica utilizada para os micronutrientes foi baseada no princípio da extração de microelementos com uso de solução quelante chamada dietilenotriaminopentacético (DTPA) em pH 7,3 e, para os macronutrientes, foi a determinação de fósforo, cálcio, potássio e magnésio extraídos com resina trocadora de íons (VAN RAIJ et al., 2001).

A amostragem de água foi feita nos igarapés afluentes do Rio Paciência, sendo alguns pontos a montante e a jusante do lixão, objetivando compreender as possíveis cargas contaminantes que podem ser provenientes das comunidades do entorno e do lixão (Figura 4).

Para tanto, foram escolhidos quatro pontos de amostragem de água superficial, cujas características estão descritas na Tabela 2.
Foram realizadas duas coletas de água em cada ponto, sendo uma no período de estiagem e outra no chuvoso. Os métodos e materiais de coletas de água para análise física e química foram baseados em CEMIG (2009), APHA (2005) e Silva et al. (2005). Já a análise de oxigênio dissolvido em laboratório foi feita de acordo com Winkler (1888) modificado por Pomeroy e Kirschman (1945). Para análise bacteriológica, foram utilizados frascos previamente esterilizados. Os parâmetros temperatura e oxigênio dissolvido foram medidos in situ por meio de oxímetro da marca Hanna, modelo HI 9146.

Já os parâmetros microbiológicos, físicos e químicos avaliados para água foram coliformes termotolerantes, temperatura, $\mathrm{pH}$, oxigênio dissolvido, sólidos totais em suspensão, turbidez, cor, salinidade, fósforo total, nitrogênio total, nitrogênio amoniacal, nitrogênio nitrito, nitrogênio nitrato, boro, zinco, níquel, manganês, magnésio, potássio, ferro, cobre, cádmio, cálcio, alumínio, chumbo, molibdênio, mercúrio, cromo e cobalto (APHA, 2005; PARANHOS, 1996; BAUMGARTEN; ROCHA; NIENCHESKI, 1996; VAN RAIJ et al., 2001).

Utilizaram-se os programas estatísticos chamados Statistical Discovery (JMP), versão 3.2.3 (SAS INSTITUTE INC, 1995) e Paleontological Statistics Software Package for Education and Data Analysis (PAST), versão 2.15 (HAMMER; HARPER; RYAN, 2001), de forma que os dados quantitativos e os qualitativos passíveis de análise estatística fossem trabalhados.

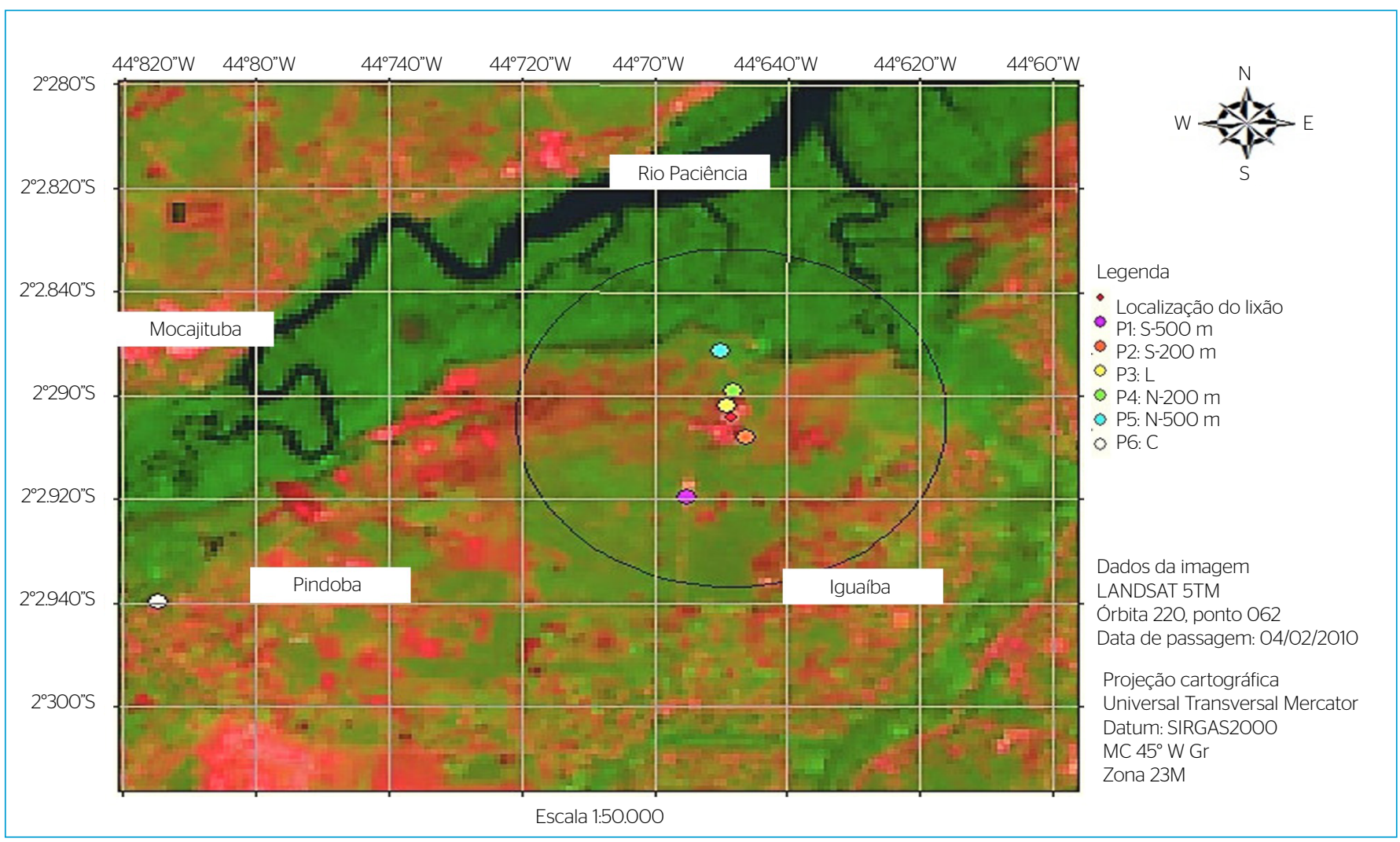

Figura 3 - Pontos de amostragem de solo na área de estudo obedecendo ao sentido sul-norte. 


\section{RESULTADOS E DISCUSSÃO}

$\mathrm{Na}$ área estudada, existem algumas atividades, além da disposição de resíduos sólidos, consideradas como atividades potencialmente contaminadoras (APC), tais como agricultura extensiva, devido ao uso de fertilizantes e agrotóxicos; fábrica de ração, por conta dos rejeitos gerados; depósito de lixo feito nos quintais das casas em função da falta do serviço de coleta de resíduos; uso de fossas e latrinas; lançamento, nas ruas, de águas residuais geradas pelas residências (com exceção da proveniente do vaso sanitário); entre outras atividades.

\section{Análise do solo}

O solo da área em estudo é arenoso com textura grossa, exceto no ponto P06-S, onde se caracteriza como franco arenoso com textura moderadamente grossa. Como se tratam de solos arenosos, apresentam porosidade alta e não possuem grande capacidade de retenção de água nem de retenção de cátions (Tabelas 3 e 4).

Os solos arenosos com textura de média a grossa em análise são classificados pela Embrapa (2006) como excessivamente a fortemente drenados. Já a relação silte/argila, de acordo com a Embrapa (2006), quando apresenta valor menor que 0,7 para solos de textura média, seus valores admitem que se trate de solo com baixo teor de silte e, portanto, com alto grau de intemperismo, fato verificado nos seis pontos analisados. Em relação à capacidade do solo de reter água, a relação entre a capacidade de campo (1/3 atm) e o ponto de murchamento (15 atm) revelou
Tabela 1 - Pontos de amostragem do solo incluindo descrições e coordenadas geográficas (Datum: SIRGAS2000).

\begin{tabular}{|c|c|c|}
\hline Pontos & Descrição & Coordenadas \\
\hline PO1-S & $\begin{array}{l}500 \text { m ao sul de PO3-S - área de solo exposto } \\
\text { e próximo à área de vegetação secundária }\end{array}$ & $\begin{array}{l}2029 ' 19,6 " \mathrm{~S} \\
44065^{\prime \prime} \mathrm{O}\end{array}$ \\
\hline PO2-S & $\begin{array}{l}200 \text { m ao sul de PO3-S - área de solo exposto } \\
\text { e próximo à área de vegetação secundária }\end{array}$ & $\begin{array}{l}\text { 2029'8,8" S; } \\
440646,1^{\prime \prime} \mathrm{O}\end{array}$ \\
\hline PO3-S & Célula utilizada para disposição & $\begin{array}{l}2029 ' 2,4^{\prime \prime} \mathrm{S} \\
44^{\circ} 649,1^{\prime \prime} \mathrm{O}\end{array}$ \\
\hline PO4-S & $\begin{array}{c}200 \text { m ao norte de PO3-S - área antiga de } \\
\text { disposição de resíduos }\end{array}$ & $\begin{array}{l}\text { 2028'59,1" S; } \\
440648,1 " \circ\end{array}$ \\
\hline P05-S & $\begin{array}{l}500 \text { m ao norte de PO3-S - próximo à } \\
\text { vegetação e em área de brejo }\end{array}$ & $\begin{array}{l}2028 ' 51,6^{\prime \prime} \mathrm{S} \\
44060^{\prime \prime} \mathrm{O}\end{array}$ \\
\hline P06-S & Controle & $\begin{array}{l}2029^{\prime} 40 " \text { S; } \\
4408^{\prime} 14,6 " \mathrm{O}\end{array}$ \\
\hline
\end{tabular}

Tabela 2 - Pontos de água amostrados contendo sua descrição e coordenadas geográficas (Datum: SIRGAS2000).

\begin{tabular}{|c|c|c|}
\hline Pontos & Descrição & Coordenadas \\
\hline P01-A & $\begin{array}{l}\text { Igarapé do Porto da Pindoba } \\
\text { recebe contribuição das comunidades } \\
\text { de Pindoba e Mocajituba }\end{array}$ & $\begin{array}{l}\text { 2029'10,3" S; } \\
4407488,8^{\prime \prime} \mathrm{O}\end{array}$ \\
\hline PO2-A & $\begin{array}{l}\text { Igarapé do Café: sem contribuições aparentes } \\
\text { do lixão e comunidades do entorno }\end{array}$ & $\begin{array}{l}\text { 2028'34," S; } \\
44077^{\prime \prime} 10,3^{\prime \prime} \mathrm{O}\end{array}$ \\
\hline PO3-A & $\begin{array}{l}\text { Igarapé do Tiririca: recebe } \\
\text { contribuição do lixão }\end{array}$ & $\begin{array}{l}\text { 2028'26.08" S; } \\
4406 \text {; } 50.15^{\prime \prime} \text { O }\end{array}$ \\
\hline PO4-A & $\begin{array}{l}\text { Igarapé do Portinho: recebe contribuição da } \\
\text { comunidade de Pindoba e Iguaíba }\end{array}$ & $\begin{array}{l}\text { 2028'20,6" S; } \\
44^{\circ} 630,1 " 0\end{array}$ \\
\hline
\end{tabular}

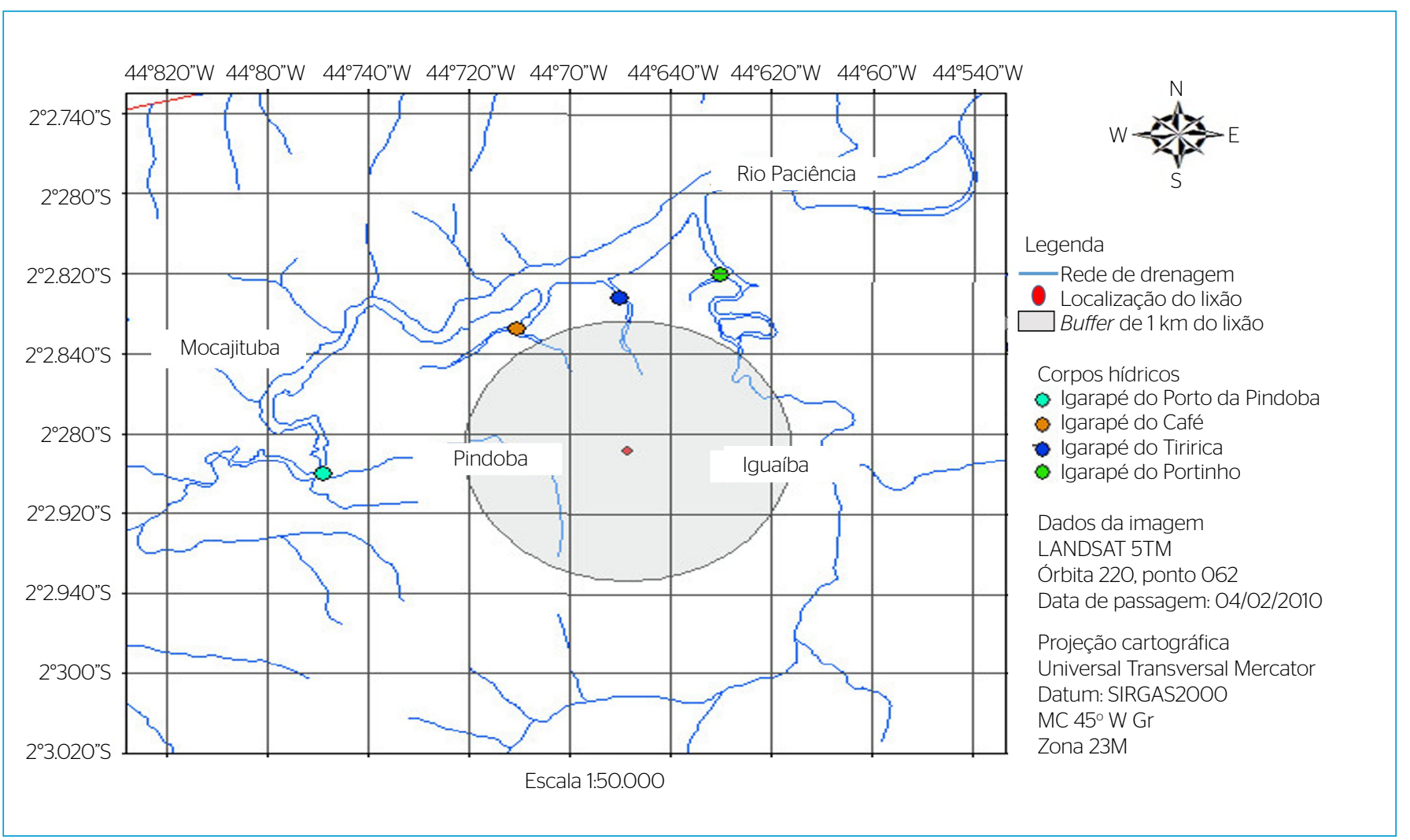

Figura 4 - Corpos hídricos dentro da área de abrangência do estudo (a 1 km do lixão), destacando-se o Rio Paciência e os seus afluentes da margem direita. 
que o percentual de água útil disponível para as plantas é considerado baixo em todos os pontos analisados (EMBRAPA, 2006).

Se a permeabilidade do solo for elevada, há alta possibilidade de ocorrer movimento de massas de poluentes descendentes para a água subterrânea (LISK, 1991). Portanto, as características do solo deste estudo são facilitadoras para a contaminação de subsolo, águas subterrâneas e águas superficiais da região.

Nos pontos P03-S e P04-S, os parâmetros $\mathrm{pH}$, fósforo, potássio, cálcio, magnésio, sódio, saturação por bases (V\%), capacidade de troca catiônica (CTC), soma de bases trocáveis (SB) e matéria orgânica foram mais elevados em comparação com os outros pontos, pois são locais onde há presença de resíduos sólidos de variadas composições, em elevada quantidade e em vários estágios de degradação (Tabela 4).

Resultados de análises realizadas por Sisinno e Moreira (1996) no aterro controlado do Morro do Céu, em Niterói (RJ), revelaram que, em geral, o chorume possui valores elevados de $\mathrm{pH}$, salinidade, condutividade, alcalinidade, dureza, cloreto, demanda bioquímica de oxigênio (DBO) e demanda química de oxigênio (DQO), fato que explica os valores diferenciados dos parâmetros analisados nos pontos P03-S e P04-S em função da presença de resíduos nesses pontos.

A saturação por bases (V\%) é maior em P03-S e P04-S, significando que há maiores quantidades de cátions $\mathrm{Ca}^{2+}, \mathrm{Mg}^{2+} \mathrm{e} \mathrm{K}^{+}$adsorvidos nos coloides que $\mathrm{Al}^{3+} \mathrm{e} \mathrm{H}^{+}$. A saturação por bases é maior nos pontos citados em função do elevado $\mathrm{pH}$ ocasionado pelo chorume gerado na decomposição dos resíduos dispostos nesses locais. Isso está diretamente ligado ao $\mathrm{pH}$, pois a elevação da saturação de bases aumenta o $\mathrm{pH}$ em função da adsorção do $\mathrm{H}^{+}$do solo e diminui a saturação por $\mathrm{Al}^{3+}$. Solos com V\% maior que $50 \%$ são considerados férteis ou eutróficos e geralmente são ricos em nutrientes, incluindo o cálcio (Ca). A soma de SB refere-se à soma de cálcio, magnésio, potássio e, se necessário, sódio, todos na sua forma de cátion trocável no solo (LOPES \& GUILHERME, 2004).

A diferença desses parâmetros identificados em P03-S e P04-S em relação aos demais pontos se deve à presença de resíduos sólidos contendo material orgânico, aumentando a CTC, a SB, a V\% e o pH, tornando esse solo mais fértil do ponto de vista da agricultura por possuírem uma maior carga de nutrientes ( $\mathrm{Na}, \mathrm{P}, \mathrm{Ca}, \mathrm{K}, \mathrm{Mg})$.

De acordo com a Embrapa (2006), o solo do P05-S é extremamente ácido, os dos pontos P01-S, P02-S e P06-S são fortemente ácidos e os dos pontos P03-S e P04-S são moderadamente ácidos. Os latossolos, tipo de solo da área em estudo, possuem características que variam de fortemente a bem drenados, fortemente ácidos, com baixa saturação por bases, distróficos ou alumínicos (EMBRAPA, 2006). Porém, essas características se alteram em P03-S e P04-S em função de conterem resíduos, elevando o $\mathrm{pH}$ do meio em virtude do caráter alcalino do chorume (OLIVEIRA \& JUCÁ, 2004).

Os pontos que mais se assimilaram ao controle (P06-S) foram os pontos P02-S e P01-S, pois ambos estão em cota topográfica mais

Tabela 4 - Resultados das análises químicas do solo, incluindo os macronutrientes.

\begin{tabular}{|c|c|c|c|c|c|c|}
\hline \multirow{2}{*}{ Parâmetros } & \multicolumn{6}{|c|}{ Período de estiagem (25/10) } \\
\hline & P01-S & P02-S & PO3-S & P04-S & P05-S & P06-S \\
\hline $\mathrm{MO}\left(\mathrm{g} / \mathrm{dm}^{3}\right)$ & 8,00 & 6,00 & 10,00 & 21,00 & 8,00 & 6,00 \\
\hline $\mathrm{pH}\left(\mathrm{CaCl}_{2}\right)$ & 4,60 & 4,50 & 6,00 & 6,40 & 3,60 & 4,40 \\
\hline$P\left(\mathrm{mg} / \mathrm{dm}^{3}\right)$ & 2,00 & 2,00 & 59,00 & 25,00 & 5,00 & 2,00 \\
\hline $\mathrm{K}\left(\mathrm{mg} / \mathrm{dm}^{3}\right)$ & 19,55 & 19,55 & 86,02 & 246,33 & 19,55 & 19,55 \\
\hline $\mathrm{Ca}\left(\mathrm{mg} / \mathrm{dm}^{3}\right)$ & 140,00 & 120,00 & 700,00 & 1260,00 & 0,00 & 100,00 \\
\hline $\operatorname{Mg}\left(\mathrm{mg} / \mathrm{dm}^{3}\right)$ & 48,62 & 24,31 & 48,62 & 85,09 & 12,16 & 36,47 \\
\hline $\mathrm{Na}\left(\mathrm{mg} / \mathrm{dm}^{3}\right)$ & 18,39 & 18,39 & 91,96 & 259,79 & 20,69 & 22,99 \\
\hline $\mathrm{SB}\left(\mathrm{mmolc} / \mathrm{dm}^{3}\right)$ & 12,30 & 9,30 & 45,10 & 87,60 & 2,30 & 9,50 \\
\hline $\mathrm{Al}\left(\mathrm{mg} / \mathrm{dm}^{3}\right)$ & 0,00 & 0,00 & 0,00 & 0,00 & 35,96 & 35,96 \\
\hline $\mathrm{H}\left(\mathrm{mg} / \mathrm{dm}^{3}\right)$ & 16,13 & 17,14 & 14,11 & 13,10 & 22,18 & 23,18 \\
\hline CTC $\left(\mathrm{mmol} / \mathrm{dm}^{3}\right)$ & 28,30 & 26,30 & 59,10 & 100,60 & 28,30 & 35,50 \\
\hline $\mathrm{Na} / \mathrm{CTC}(\%)$ & 2,90 & 3,10 & 6,70 & 11,20 & 3,10 & 2,70 \\
\hline Al/Al+SB (\%) & 0,00 & 0,00 & 0,00 & 0,00 & 63,20 & 27,00 \\
\hline V (\%) & 43,40 & 35,40 & 76,30 & 87,10 & 8,20 & 26,70 \\
\hline
\end{tabular}

SB: soma de bases trocáveis; V: saturação por bases.

Tabela 3 - Resultados das análises físicas do solo contendo informações sobre a composição granulométrica, proporção silte/argila, textura, densidade, porosidade e capacidade do solo em reter água.

\begin{tabular}{|c|c|c|c|c|c|c|c|c|c|c|c|c|}
\hline \multirow[b]{2}{*}{ Ponto } & \multicolumn{4}{|c|}{ Composição granulométrica (\%) } & \multirow{2}{*}{$\begin{array}{l}\text { Silte/ } \\
\text { argila }\end{array}$} & \multirow[b]{2}{*}{ Textura } & \multicolumn{2}{|c|}{ Densidade $\left(\mathrm{g} / \mathrm{cm}^{3}\right)$} & \multirow{2}{*}{$\begin{array}{l}\text { Porosidade } \\
\text { (\%) }\end{array}$} & \multicolumn{3}{|c|}{$\mathrm{H}_{2} \mathrm{O}(\%)$} \\
\hline & $\begin{array}{c}\text { Areia } \\
\text { grossa }\end{array}$ & $\begin{array}{l}\text { Areia } \\
\text { fina }\end{array}$ & Silte & Argila & & & Aparente & Real & & $1 / 3 \mathrm{~atm}$ & $15 \mathrm{~atm}$ & Útil \\
\hline PO1-S & 19 & 71 & 2 & 8 & 0,25 & Areia & 1,23 & 2,64 & 53 & 18 & 8 & 10 \\
\hline PO2-S & 24 & 66 & 2 & 8 & 0,25 & Areia & 1,33 & 2,77 & 52 & 18 & 8 & 10 \\
\hline PO3-S & 18 & 73 & 2 & 7 & 0,29 & Areia & 1,41 & 2,62 & 46 & 17 & 8 & 9 \\
\hline PO4-S & 25 & 63 & 2 & 10 & 0,20 & Areia franca & 1,32 & 2,61 & 49 & 18 & 10 & 8 \\
\hline P05-S & 18 & 77 & 1 & 4 & 0,25 & Areia & 1,36 & 2,73 & 50 & 16 & 7 & 9 \\
\hline P06-S & 14 & 63 & 5 & 18 & 0,28 & Franco arenoso & 1,39 & 2,65 & 47 & 22 & 10 & 12 \\
\hline
\end{tabular}

Areia grossa: 2-0,2 mm; areia fina: 0,2-0,05; silte: 0,05-0,002; argila: $<0,002$. 
elevada em relação à área do lixão. Já o ponto P05-S diferencia-se de todos os pontos mesmo estando em cota mais baixa em relação ao lixão, pois não recebe influência de contaminação direta na superfície do solo e está próximo à área com vegetação que pode atenuar os efeitos dos poluentes (Figura 5).

A análise química dos micronutrientes do solo revelou que os pontos P03-S e P04-S obtiveram níveis altos de contaminação, evidenciando a contribuição do lixão como propagador de contaminantes ambientais. O mercúrio foi detectado em todos os pontos, inclusive no controle, acima do valor máximo permitido (VMP) pela Resolução CONAMA $\mathrm{n}^{\circ}$ 420, de 28 de dezembro de 2009 (BRASIL, 2009) (Tabela 5).

Trabalho realizado por Sisinno e Moreira (1996) no aterro controlado do Morro do Céu (Niterói, RJ) apresentou elevada contaminação orgânica e baixa contaminação por metais. Porém, mesmo em baixas concentrações, metais como cádmio, cromo, cobre, chumbo e zinco estavam em níveis mais elevados em áreas com influência direta do aterro controlado, fato que confirma o processo de contaminação da região do entorno. No lixão de Paço do Lumiar, todos os metais detectados por Sisinno e Moreira (1996), com exceção do cromo, foram detectados, porém em níveis mais elevados.

A presença de zinco no ponto P04-S compromete o uso agrícola e residencial nessa localidade. $\mathrm{O}$ cobre foi um micronutriente encontrado apenas nos pontos P02-S, P03-S e P04-S, porém deve-se ter uma atenção especial a esse parâmetro, pois em P03-S apresenta níveis de prevenção acima do VMP. Já o ferro está presente em todos os pontos, contudo os valores dos pontos P03-S e P04-S são muito elevados em comparação com os outros pontos. Análise do chorume percolado no aterro da Muribeca, em Recife (PE), realizada por Oliveira e Jucá (2004), revelou que os elementos mais concentrados nesse percolado eram o ferro e o alumínio e atribuíram esse fato à corrosão e/ou à biodeterioração de materiais metálicos confinados no aterro.

O chumbo obteve valores significativos nos pontos P03-S e P04$\mathrm{S}$, sendo que, nesse último, tem seu uso residencial comprometido e o primeiro (P03-S) está com valor próximo ao limite estabelecido para prevenção. Já o cádmio foi detectado apenas no ponto P04-S e, em função disso, compromete o uso residencial desse ponto.

Comparando-se dados de diversas áreas de disposição de resíduos sólidos, tais como o lixão de Apodi (RN), o lixão desativado de Lages

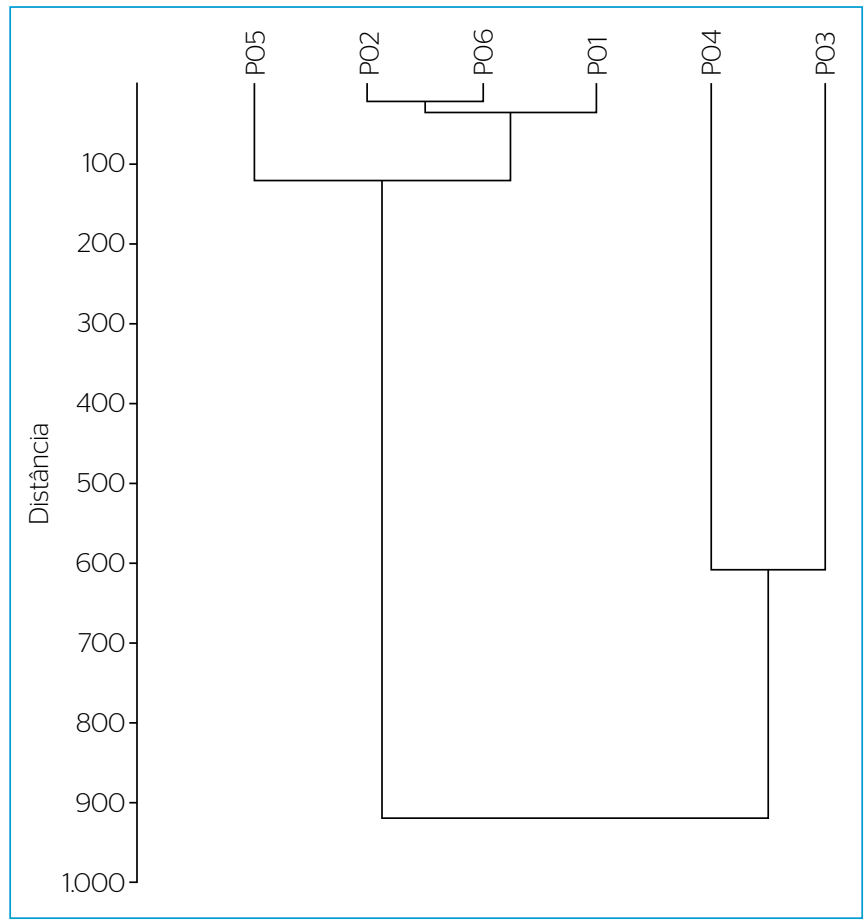

Figura 5 - Similaridade dos pontos de solo amostrados em relação a análises químicas, incluindo os macronutrientes.

Tabela 5 - Resultados das análises químicas dos micronutrientes do solo.

\begin{tabular}{|c|c|c|c|c|c|c|c|c|c|c|c|}
\hline \multirow{2}{*}{$\begin{array}{l}\text { Parâmetros } \\
\left(\mathrm{mg} / \mathrm{dm}^{3}\right)\end{array}$} & \multicolumn{6}{|c|}{ Período de estiagem (25/10) } & \multirow{2}{*}{$\begin{array}{l}\text { Limite de } \\
\text { detecção }\end{array}$} & \multicolumn{4}{|c|}{$\begin{array}{l}\text { VMP (mg/dm³), Resolução CONAMA } \\
\text { n० } 420 \text {, de } 28 \text { de dezembro de } 2009\end{array}$} \\
\hline & P01 & P02 & PO3 & P04 & P05 & P06 & & $\begin{array}{l}\text { Preven- } \\
\text { ção }\end{array}$ & $\begin{array}{l}\text { Agrícola } \\
\text { (I) }\end{array}$ & $\begin{array}{l}\text { Residencial } \\
\text { (I) }\end{array}$ & $\begin{array}{l}\text { Industrial } \\
\text { (I) }\end{array}$ \\
\hline Zn & $N D^{*}$ & $N D^{*}$ & 295,04 & $1.201,87^{*}$ & 0,88 & $N D^{*}$ & 0,0002 & 300 & 450 & 1.000 & 2.000 \\
\hline $\mathrm{Cu}$ & $N D^{*}$ & 0,57 & $113,90^{*}$ & 52,23 & $N D^{*}$ & $N D^{*}$ & 0,0003 & 60 & 200 & 400 & 600 \\
\hline $\mathrm{Fe}$ & $1.115,04$ & 599,40 & $1.349,59$ & $1.384,86$ & 182,43 & 430,01 & 0,0001 & - & - & - & - \\
\hline $\mathrm{Mn}$ & 5,4940 & $N D^{*}$ & 28,25 & 29,04 & ND* & 3,92 & 0,00003 & - & - & - & - \\
\hline B & 0,33 & 0,30 & 2,18 & 0,82 & 0,28 & 0,66 & 0,0001 & - & - & - & - \\
\hline $\mathrm{Pb}$ & 8,60 & $N D^{*}$ & 69,57 & $239,10^{*}$ & 10,30 & 21,40 & 0,0008 & 72 & 180 & 300 & 900 \\
\hline $\mathrm{Cd}$ & $N D^{*}$ & $N D^{*}$ & $N D^{*}$ & $4,44^{*}$ & $N D^{*}$ & $N D^{*}$ & 0,00005 & 1,3 & 2 & 8 & 20 \\
\hline $\mathrm{Ni}$ & $N D^{*}$ & $N^{*}$ & $N D^{*}$ & 1,66 & $N^{*}$ & $N D^{*}$ & - & 30 & 70 & 100 & 130 \\
\hline $\mathrm{Hg}$ & $43,63^{*}$ & $44,53^{*}$ & $45,43^{*}$ & $41,22^{*}$ & $40,6^{*}$ & $39,30^{*}$ & 0,0008 & 0,5 & 12 & 36 & 70 \\
\hline $\mathrm{Cr}$ & $\mathrm{ND}^{*}$ & $N D^{*}$ & $N D^{*}$ & $N D^{*}$ & $N D^{*}$ & $N D^{*}$ & 0,00015 & 75 & 150 & 300 & 400 \\
\hline
\end{tabular}

ND: não detectado; VMP: valor máximo permitido; *valores em negrito estão acima do VMP de acordo com a Resolução CONAMA no 420, de 2009 (BRASIL, 2009 ). 
(SC), o lixão de Visconde do Rio Branco (MG) e de aterros do Estado do Rio Grande do Norte, contidos no trabalho de Pinto-Filho et al. (2012), com os detectados no município de Paço do Lumiar, verificou-se que os níveis de zinco, ferro, cobre, cádmio e chumbo estão bastante elevados, chegando alguns destes a superar os valores encontrados por Pinto-Filho et al. (2012) (Tabela 6).

É importante destacar que, no lixão de Santa Catarina desativado, ainda se verifica a presença de contaminantes como cádmio, cromo, níquel e chumbo em virtude de sua recalcitrância no ambiente. No aterro do Rio Grande do Norte, mesmo com melhor infraestrutura, há contaminação alta por cádmio, cromo, níquel e chumbo, enfatizando que a disposição de resíduos sólidos é fonte de contaminantes em potencial para o ambiente.

Em trabalho realizado por Marques (2011) em três áreas de disposição, sendo um aterro sanitário, um controlado e um lixão já desativado, detectou-se a presença de contaminantes no solo como cobre acima do valor de prevenção e níquel e cromo acima dos valores de intervenção, sendo níveis mais elevados a jusante do que no próprio local de disposição. Isso pode ser explicado em decorrência de os metais pesados terem capacidade de recalcitrância e, portanto, serem cumulativos no ambiente (MARQUES, 2011). O mesmo fato observado por Marques (2011) foi evidente neste estudo: o de que, em alguns casos, o ponto P04-S apresentou valores de metais mais elevados que P03-S.

\section{Análise da água}

A temperatura da água no período de estiagem teve média de $30,3^{\circ} \mathrm{C}$, com desvio padrão de $1,01^{\circ} \mathrm{C}$; já no período chuvoso, a média foi $29,25^{\circ} \mathrm{C}$, com desvio padrão de $0,5^{\circ} \mathrm{C}$. A salinidade medida na primeira coleta foi de 1,14\%o no P01-A, de 2,67\% no P02-A, de 2,81\%o no P03-A e de 2,84\% no P04-A, aumentando em direção à foz do rio (Tabela 7).

De acordo com a salinidade e com os usos do trecho em estudo (igarapés), fez-se a classificação, de acordo a Resolução CONAMA $\mathrm{n}^{\circ} 357$, de 17 de março de 2005, desse corpo hídrico em água salobra e pertencente à classe 1 . Portanto, todos os valores de referência para os parâmetros analisados foram baseados nessa classificação (BRASIL, 2005).

Parâmetros orgânicos, como nitrogênio amoniacal, nitrogênio nitrito e nitrogênio nitrato apresentaram VMP pela norma, indicando que há um lançamento de carga orgânica constante nesses ambientes; os resultados para amônia revelaram que, no período chuvoso, o lançamento de carga orgânica foi mais intenso. Os inorgânicos, incluindo os metais pesados, o boro e o chumbo, estavam presentes em todos os pontos amostrados acima do VMP (Tabela 8).

Em estudo realizado por Marques (2011) em corpos hídricos superficiais que recebem influência da área de disposição de resíduos sólidos, no período de estiagem, foram identificados valores

Tabela 6 - Níveis de metais pesados encontrados no lixão de Paço do Lumiar em comparação com outros locais de disposição de resíduos sólidos.

\begin{tabular}{|c|c|c|c|c|c|c|}
\hline Metais pesados & $\begin{array}{l}\text { Lixão Paço do } \\
\text { Lumiar (PO3-S) }\end{array}$ & $\begin{array}{l}\text { Lixão Paço do } \\
\text { Lumiar (P04-S) }\end{array}$ & Lixão do Apodi (RN) & $\begin{array}{l}\text { Lixão de Lages } \\
\text { (desativado) (SC) }\end{array}$ & $\begin{array}{l}\text { Lixão de Visconde } \\
\text { do Rio Branco (MG) }\end{array}$ & $\begin{array}{l}\text { Aterros do Rio } \\
\text { Grande do Norte }\end{array}$ \\
\hline $\mathrm{Cd}\left(\mathrm{mg} / \mathrm{dm}^{3}\right)$ & ND & 4,44 & 0,36 & 0,2 & 1,62 & 6,43 \\
\hline $\mathrm{Cu}\left(\mathrm{mg} / \mathrm{dm}^{3}\right)$ & 113,9 & 52,23 & 57,6 & - & 65,07 & - \\
\hline $\mathrm{Fe}\left(\mathrm{mg} / \mathrm{dm}^{3}\right)$ & 1349,59 & 1384,86 & 34,56 & - & 34,43 & - \\
\hline $\mathrm{Ni}\left(\mathrm{mg} / \mathrm{dm}^{3}\right)$ & ND & 1,663 & 8,9 & 7,2 & 43,6 & 48,42 \\
\hline $\mathrm{Pb}\left(\mathrm{mg} / \mathrm{dm}^{3}\right)$ & 69,57 & 239,1 & 139,0 & 8,9 & 28,62 & 106,23 \\
\hline $\mathrm{Zn}\left(\mathrm{mg} / \mathrm{dm}^{3}\right)$ & 295,04 & 1201,87 & 256,9 & - & 0,78 & - \\
\hline
\end{tabular}

Fonte: dados do lixão de Paço do Lumiar e Pinto-Filho et al. (2012).

Tabela 7 - Parâmetros físicos dos quatro pontos de amostragem de água.

\begin{tabular}{|c|c|c|c|c|c|c|c|c|c|}
\hline \multirow{2}{*}{ Parâmetros } & \multicolumn{4}{|c|}{ Período de estiagem (22/01) } & \multicolumn{4}{|c|}{ Período chuvoso $(20 / 03)$} & \multirow{2}{*}{$\begin{array}{l}\text { VMP; CONAMA no } \\
\text { 357/2005; classe } 1\end{array}$} \\
\hline & P01-A & PO2-A & PO3-A & P04-A & P01-A & $\mathrm{PO} 2-\mathrm{A}$ & P03-A & P04-A & \\
\hline $\mathrm{pH}$ & 6,63 & 7,22 & 7,52 & 7,16 & 6,81 & 7,15 & 7,61 & 7,13 & 6,5 a 8,5 \\
\hline $\mathrm{O}_{2}\left(\mathrm{mg} \mathrm{L}^{-1}\right)$ & 5,59 & 6,04 & 6,70 & 7,00 & 5,85 & 6,00 & 5,58 & 6,65 & Não inferior a 5 mg. $\mathrm{L}^{-1}$ \\
\hline $\begin{array}{l}\text { Sólidos totais em } \\
\text { suspensão }\left(\mathrm{mg}^{-L^{-1}}\right)\end{array}$ & 6,80 & 9,30 & 10,45 & 10,26 & 57,00 & 25,00 & 38,00 & 28,00 & - \\
\hline Turbidez (FTU) & 12,00 & 12,00 & 13,00 & 14,00 & 95,00 & 22,00 & 20,00 & 11,00 & - \\
\hline Cor (Pt Co cor) & 37,00 & 31,00 & 27,00 & 29,00 & 44,00 & 25,00 & 17,00 & 11,00 & - \\
\hline
\end{tabular}

VMP: valor máximo permitido. 
de alguns parâmetros acima do VMP, porém, no período chuvoso, esses níveis se intensificavam. Nesse mesmo trabalho, foram detectados em corpos hídricos superficiais próximos a áreas de disposição de resíduos sólidos, incluindo um aterro sanitário, níveis elevados de DBO, cor, turbidez e amônia. Fora da área de influência dos locais de disposição analisados por Marques (2011), foram detectados também altos níveis de fósforo, ferro, alumínio, mercúrio, zinco e manganês. Isso evidencia que podem as águas superficiais carregar consigo outras informações contidas de fontes de contaminação diversas.
Em todos os pontos de amostragem de água, foi detectada a presença de Escherichia coli. Os pontos com maior representatividade em relação ao número mais provável por $100 \mathrm{ml}$ de coliformes termotolerantes foram o P01-A e o P04-A, pois estão mais próximos às comunidades. O ponto P02-A é o menor receptor de contaminação, pois não há carga contaminante lançada diretamente no corpo hídrico, porém as análises microbiológicas evidenciaram que o Igarapé do Café recebe contaminantes que podem ter origem no lixão ou em outras fontes. O P03-A é o que tem maior probabilidade de ser influenciado pela presença do lixão em virtude da topografia local (Tabela 9).

Tabela 8 - Parâmetros químicos orgânicos e inorgânicos dos quatro pontos de amostragem de água.

\begin{tabular}{|c|c|c|c|c|c|c|c|c|c|c|}
\hline \multirow{2}{*}{$\begin{array}{l}\text { Parâmetros } \\
\left(\mathrm{mg} \cdot \mathrm{L}^{-1}\right)\end{array}$} & \multicolumn{4}{|c|}{ Período de estiagem (22/01) } & \multicolumn{4}{|c|}{ Período chuvoso $(20 / 03)$} & \multirow{2}{*}{$\begin{array}{l}\text { Limite de } \\
\text { detecção }\end{array}$} & \multirow{2}{*}{$\begin{array}{l}\text { VMP (mg.L-1); CONAMA } \\
\text { n } 357 / 2005 \text {, classe } 1\end{array}$} \\
\hline & P01-A & $\mathrm{PO}-\mathrm{A}$ & PO3-A & P04-A & P01-A & P02-A & PO3-A & P04-A & & \\
\hline Fósforo total & 0,37 & 0,21 & 0,20 & 0,25 & 0,83 & 0,21 & 0,17 & 0,13 & 0,0015 & -- \\
\hline Nitrogênio total & 0,85 & 0,50 & 0,60 & 0,40 & 6,95 & 1,45 & 1,00 & 0,90 & -- & -- \\
\hline Amônia & 0,17 & $0,52^{*}$ & 0,18 & 0,23 & $1,40^{*}$ & $0,70^{*}$ & $0,60^{*}$ & 0,40 & -- & 0,40 \\
\hline Nitrito & $0,09^{*}$ & 0,03 & 0,02 & 0,02 & 0,07 & 0,01 & 0,01 & 0,00 & -- & 0,07 \\
\hline Nitrato & $0,80^{*}$ & $0,65^{*}$ & $0,55^{*}$ & $0,50^{*}$ & $1,40^{*}$ & $0,70^{*}$ & $0,60^{*}$ & 0,40 & -- & 0,40 \\
\hline Boro & $2,08^{*}$ & $2,56^{*}$ & $2,75^{*}$ & $2,68^{*}$ & $1,28^{*}$ & $2,42^{*}$ & $2,61^{*}$ & $2,74^{*}$ & 0,0001 & 0,5 \\
\hline Zinco & $N D^{*}$ & $N D^{*}$ & $N D^{*}$ & $N D^{*}$ & $N D^{*}$ & $N D^{*}$ & $N D^{*}$ & $N D^{*}$ & 0,0002 & 0,09 \\
\hline Níquel & $N D^{*}$ & $N D^{*}$ & $N D^{*}$ & $N^{*}$ & 0,02 & $N D^{*}$ & $\mathrm{ND}^{*}$ & $N D^{*}$ & -- & 0,025 \\
\hline Manganês & $N D^{*}$ & $N D^{*}$ & $N D^{*}$ & $N D^{*}$ & 0,02 & $N D^{*}$ & $\mathrm{ND}^{*}$ & $N D^{*}$ & 0,00003 & 0,1 \\
\hline Magnésio & 60,45 & 58,64 & 58,69 & 57,55 & 40,12 & 37,38 & 37,60 & 36,84 & 0,00001 & -- \\
\hline Potássio & 156,50 & 181,50 & 187,90 & 180,50 & 55,03 & 103,20 & 109,80 & 115,10 & 0,0003 & -- \\
\hline Ferro & $\mathrm{ND}^{*}$ & $N D^{*}$ & $N D^{*}$ & $N D^{*}$ & 0,05 & $N D^{*}$ & $\mathrm{ND}^{*}$ & $N D^{*}$ & 0,0001 & 0,3 \\
\hline Cobre & $\mathrm{ND}^{*}$ & $N D^{*}$ & $N^{*}$ & $N D^{*}$ & $N D^{*}$ & $N D^{*}$ & $\mathrm{ND}^{*}$ & $N D^{*}$ & 0,0003 & 0,005 \\
\hline Cádmio & $N D^{*}$ & $N D^{*}$ & $N^{*}$ & $\mathrm{ND}^{*}$ & 0,01 & $N D^{*}$ & $\mathrm{ND}^{*}$ & $\mathrm{ND}^{*}$ & 0,00005 & 0,005 \\
\hline Cálcio & 65,65 & 64,74 & 64,59 & 65,22 & 18,59 & 18,70 & 18,78 & 18,80 & 0,00001 & -- \\
\hline Alumínio & $\mathrm{ND}^{*}$ & $N D^{*}$ & $N D^{*}$ & $N D^{*}$ & $0,13^{*}$ & 0,06 & $\mathrm{ND}^{*}$ & $\mathrm{ND}^{*}$ & 0,0001 & 0,1 \\
\hline Chumbo & $1,45^{*}$ & $2,17^{*}$ & $1,86^{*}$ & $1,79^{*}$ & -- & -- & -- & --- & 0,0008 & 0,01 \\
\hline Molibdênio & 0,03 & 0,07 & 0,10 & 0,04 & -- & -- & -- & -- & 0,0005 & -- \\
\hline Mercúrio & 0,03 & 0,01 & 0,01 & $N D^{*}$ & -- & -- & --- & -- & 0,0008 & 0,0002 \\
\hline Cromo & $N D^{*}$ & $N D^{*}$ & $N D^{*}$ & $N D^{*}$ & $N D^{*}$ & $N^{*}$ & $N D^{*}$ & $N D^{*}$ & 0,00015 & 0,05 \\
\hline Cobalto & $N D^{*}$ & $N D^{*}$ & $N D^{*}$ & $N D^{*}$ & $N D^{*}$ & $N D^{*}$ & $N D^{*}$ & $N D^{*}$ & -- & -- \\
\hline
\end{tabular}

ND: não detectado; VMP: valores máximos permitidos; *valores em negrito estão acima do VMP de acordo com a Resolução CONAMA no 357, de 2005 (BRASIL, 2005).

Tabela 9 - Pontos de água amostrados contendo o NMP.100 $\mathrm{ml}^{-1}$ e Escherichia coli.

\begin{tabular}{l|c|c|c|c}
\multirow{2}{*}{ Pontos } & \multicolumn{2}{|c|}{ Período de estiagem (22/01) } & Período chuvoso (20/03) \\
\cline { 2 - 5 } & $\begin{array}{c}\text { Coliformes termotolerantes } \\
\left(\mathrm{NMP} .100 \mathrm{ml}^{-1}\right)\end{array}$ & Escherichia coli & $\begin{array}{c}\text { Coliformes termotolerantes } \\
(\text { NMP.100 ml') }\end{array}$ & Escherichia coli \\
\hline PO1-A & $2.400^{*}$ & Presença & $2.400^{*}$ & Presença \\
\hline PO2-A & 23 & Presença & $460^{*}$ & Presença \\
\hline PO3-A & 150 & Presença & $1.100^{*}$ & Presença \\
\hline PO4-A & $2.400^{*}$ & Presença & $1.100^{*}$ & Presença \\
\hline
\end{tabular}

*Valores em negrito estão acima do valor máximo permitido (VMP) de acordo com a Resolução CONAMA no 274, de 2000, ou Resolução CONAMA no 357, de 2005 (BRASIL, 2000; 2005). 
Há uma variação em relação ao desvio padrão nos dois períodos analisados, pois, no período de estiagem, os pontos P01-A e P04-A obtiveram valores mais elevados que os outros dois em decorrência de receberem esgoto de comunidades; já no período chuvoso, a quantidade de coliformes termotolerantes aumenta em virtude da lavagem do solo que carreia para esses ambientes mais contaminantes, fator que contribuiu para diminuir o desvio padrão no período chuvoso (Figura 6).

\section{Classificação final}

De acordo com a Resolução CONAMA n 420, de 28 de dezembro de 2009, que dispõe sobre os critérios de qualidade do solo (BRASIL, 2009), o P04-S apresentou valores acima do VMP para os parâmetros zinco, chumbo, cádmio e mercúrio, comprometendo os usos da agricultura e residencial. Em P03-S, além do mercúrio, o cobre está acima do valor permitido para prevenção. Somente em relação ao parâmetro do mercúrio foram encontrados níveis que comprometem os usos agrícolas e residenciais em todos os pontos avaliados (Tabela 10).

Já em relação à água, os resultados dos parâmetros inorgânicos foram pouco representativos para confirmar que o lixão seja um grande contribuinte para a contaminação dos corpos hídricos da região. O uso do solo na bacia reflete significativamente na qualidade da água da região. Assim, confirma-se a contaminação de todos os pontos analisados, mas não se pode dizer que o lixão seja o maior contribuinte para tal (Tabela 11).
Tabela 10 - Informação sobre áreas contaminadas (solo) por influência ou não do lixão relacionando ponto com os parâmetros detectados acima do valor máximo permitido.

\begin{tabular}{l|c|c} 
Pontos & $\begin{array}{c}\text { Parâmetros acima do VMP } \\
\text { (influência do lixão) }\end{array}$ & $\begin{array}{c}\text { Parâmetros acima do VMP } \\
\text { (sem influência do lixão) }\end{array}$ \\
\hline P01-S & - & $\mathrm{Hg}$ \\
\hline P02-S & - & $\mathrm{Hg}$ \\
\hline P03-S & $\mathrm{Hg} \mathrm{e} \mathrm{Cu}$ & $\mathrm{Hg}$ \\
\hline P04-S & $\mathrm{Hg}, \mathrm{Pb}, \mathrm{Cd} \mathrm{e} \mathrm{Zn}$ & $\mathrm{Hg}$ \\
\hline P05-S & - & $\mathrm{Hg}$ \\
\hline P06-S & - & $\mathrm{Hg}$
\end{tabular}

VMP: valor máximo permitido.

Tabela 11 - Informações contendo os parâmetros acima do valor máximo permitido em cada ponto de amostragem de água nos períodos de estiagem e chuvoso.

\begin{tabular}{c|c|c} 
Pontos & $\begin{array}{c}\text { Parâmetros acima } \\
\text { do VMP (estiagem) }\end{array}$ & $\begin{array}{c}\text { Parâmetros acima } \\
\text { do VMP (chuvoso) }\end{array}$ \\
\hline PO1-A & $\begin{array}{c}\text { Nitrito, nitrato, boro, } \\
\text { chumbo e mercúrio }\end{array}$ & $\begin{array}{c}\text { Amônia, nitrato, } \\
\text { boro e alumínio }\end{array}$ \\
\hline P02-A & $\begin{array}{c}\text { Amônia, nitrato, boro, } \\
\text { chumbo e mercúrio }\end{array}$ & Amônia, nitrato e boro \\
\hline PO3-A & $\begin{array}{c}\text { Nitrato, boro, chumbo e } \\
\text { mercúrio }\end{array}$ & Amônia, nitrato e boro \\
\hline PO4-A & $\begin{array}{c}\text { Nitrato, boro, chumbo e } \\
\text { mercúrio }\end{array}$ & Boro \\
\hline
\end{tabular}

VMP: valor máximo permitido.

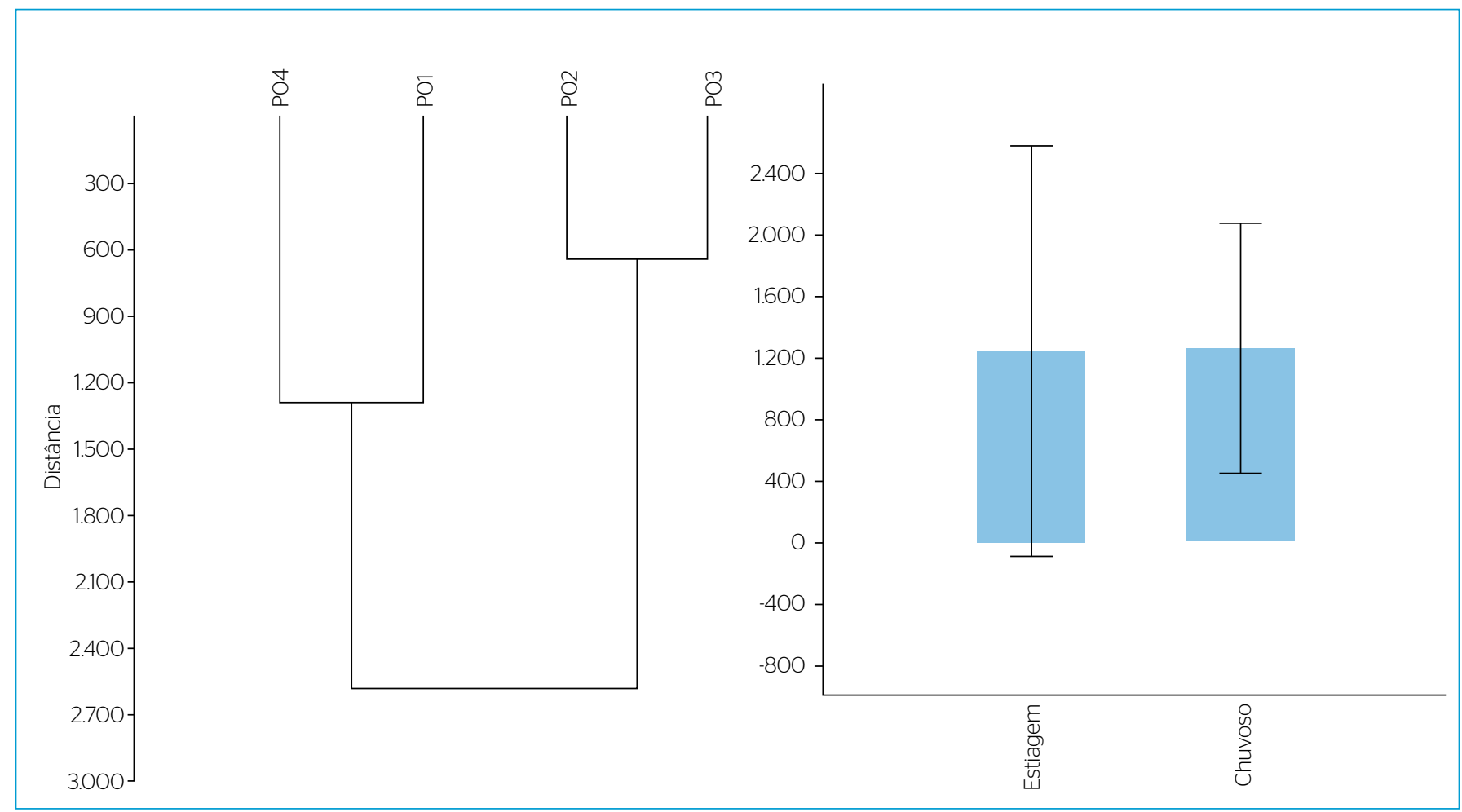

Figura 6 - Análise de Cluster e gráfico de barras contendo informações sobre similaridade entre os pontos e o desvio padrão dos resultados de análise de coliformes termotolerantes. 
Mesmo não entrando como parâmetro classificador, o número mais provável de coliformes termotolerantes por $100 \mathrm{ml}$ não pode ser desconsiderado em função dos altos valores assumidos, principalmente em pontos com influência direta das comunidades.

O mercúrio encontrado no solo e na água superficial pode ter outras origens que não a do lixão. Micaroni, Bueno e Jardim (2000) destacam que a origem antrópica do mercúrio pode estar associada a indústrias que queimam combustíveis fósseis, incineradores de lixo, polpa de papel, tintas, pesticidas, fungicidas, lâmpadas de vapor de mercúrio, baterias e outras fontes. O mercúrio também pode ter origem natural ligada a diversos fatores, com destaque para fatores geológicos. Porém, destaca-se na área de estudo a atividade intensa da agricultura que poderia ser uma hipótese de fonte de contaminação por mercúrio em função dos pesticidas utilizados, fato que pode ser investigado em estudos posteriores.

\section{CONCLUSÃO}

A atividade de disposição final de resíduos sólidos no município de Paço do Lumiar tem levado à contaminação dos solos da região e, consequentemente, ao comprometimento dos usos residencial e agrícola das áreas analisadas. Portanto, os pontos com influência direta do lixão foram classificados como áreas contaminadas em virtude da presença de metais pesados acima do VMP pela Resolução CONAMA n 420, de 2009.

No entanto, verificou-se, por meio da análise de água, que os usos da bacia do Rio Paciência são fatores que determinam a contaminação dos corpos hídricos superficiais da região e que o lixão pode ser mais uma das atividades que podem contribuir para tal fato.

Porém, há a necessidade de estudos posteriores e mais detalhados que possam avaliar os riscos inerentes aos compartimentos ambientais da região com intuito de remediação. Além disso, o monitoramento da área deve ser feito de forma contínua, mesmo que o lixão seja desativado futuramente.

\section{REFERÊNCIAS}

AMERICAN PUBLIC HEALTH ASSOCIATION (APHA). (2005) Standard methods for the examination of water and wastewater. 21. ed. Washington, D.C.: APHA.

ARAÚJO, E.P.; TELES, M.G.L.; LAGO, W.J.S. (2009) Delimitação das bacias hidrográficas da Ilha do Maranhão a partir de dados SRTM. In: SIMPÓSIO BRASILEIRO DE SENSORIAMENTO REMOTO, 16., 2009, Natal. Anais... Natal: INPE. p. 4631-4638.

BAUMGARTEN, M.G.Z; ROCHA, J.M. de B.; NIENCHESKI, L.F.H. (1996) Manual de análises em oceanografia química. Rio Grande: Editora da FURG.

BRASIL. (1981) Lei Federal no 6.938, de 31 de agosto de 1981. Dispõe sobre a Política Nacional do Meio Ambiente, seus fins e mecanismos de formulação e aplicação, e dá outras providências. Disponível em: <http://www.planalto.gov.br/ccivil_O3/LEIS/L6938. htm>. Acesso em: 02 maio 2016.

(2005) Resolução CONAMA no 357, de 17 de março de 2005. Dispõe sobre a classificação dos corpos de água e diretrizes ambientais para o seu enquadramento, bem como estabelece as condições e padrões de lançamento de efluentes, e dá outras providências. Disponível em: <http:// www.mma.gov.br/port/conama/res/res05/res35705.pdf>. Acesso em: 14 maio 2016.

(2009) Resolução CONAMA no 420, de 28 de dezembro de 2009. Dispõe sobre critérios e valores orientadores de qualidade do solo quanto à presença de substâncias químicas e estabelece diretrizes para o gerenciamento ambiental de áreas contaminadas por essas substâncias em decorrência de atividades antrópicas. Disponível em: <http://www.mma.gov.br/port/conama/legiabre. cfm?codlegi=620>. Acesso em: 14 maio 2016.

BYRNES, M.E. (1994) Field sampling methods for remedial investigations. Florida: CRC Press.
COMPANHIA AMBIENTAL DO ESTADO DE SÃO PAULO (CETESB/ GTZ). (1999) Manual de gerenciamento de áreas contaminadas. São Paulo: Cooperação Técnica Brasil-Alemanha CETESB/GTZ.

COMPANHIA ENERGÉTICA DE MINAS GERAIS (CEMIG). (2009) Manual de procedimentos de coleta e Metodologia de análise de água. Belo Horizonte: Cemig.

EMPRESA BRASILEIRA DE PESQUISA AGROPECUÁRIA (EMBRAPA). (2006) Sistema Brasileiro de classificação de solos. 2. ed. Rio de Janeiro: EMBRAPA-SPI

FEITOSA, A.C:; TROVÃO, J.R. (2006) Atlas escolar do Maranhão: espaço geo-histórico e cultural. João Pessoa: Grafiset.

GUERRA, A.J.T.; CUNHA, S.B. da. (2005) Impactos ambientais urbanos no Brasil. 3. ed. Rio de Janeiro: Bertrand Brasil.

HAMMER, Ø.; HARPER, D.A.T; RYAN, P.D. (2001) PAST: Paleontological Statistics software package for education and data analysis (PAST) versão 2.15. Paleontological Electronica, v. 4, n. 1.

INSTITUTO BRASILEIRO DE GEOGRAFIA E ESTATIŚSTICA (IBGE). (2002) Atlas Nacional do Brasil. Rio de Janeiro: IBGE.

(20101) Cidades: Dados do Município de São Luís - Censo 2010. Rio de Janeiro: IBGE. Disponível em: <www.ibge.gov.br/ cidadesat/>. Acesso em: 10 out. 2012.

(2010b) Pesquisa nacional de saneamento básico 2008. Rio de Janeiro: IBGE. Disponível em: <https://ww2.ibge.gov.br/home/ presidencia/noticias/imprensa/ppts/0000000105.pdf>. Acesso em: 10 nov. 2016

LISK, D.J. (1991) Environmental effects of landfills. The Science of the Total Environment, Amsterdã, v. 100, p. 415-468. https://doi. org/10.1016/0048-9697(91)90387-T 
LOPES, A.S.; GUILHERME, L.R.G. (2004) Interpretação da Análise do Solo: Conceitos e aplicações. São Paulo: Atual. 51 p. (Boletim Técnico, n. 2).

MARANHÃO. (1991) Diagnóstico dos principais problemas ambientais do Estado do Maranhão. São Luís: IBAMA/SEMATUR.

MARQUES, R.F. de P.V. (2011) Impactos ambientais da disposição de resíduos sólidos urbanos no solo e na água superficial em três municípios de Minas Gerais. 95f. Dissertação (Mestrado em Recursos Hídricos em Sistemas Agrícolas) - Universidade Federal de Lavras, Lavras.

MICARONI, R.C.C.M.; BUENO, M.I.M.S.; JARDIM, W.F. (2000) Compostos de mercúrio. Revisão de métodos de determinação, tratamento e descarte. Química Nova, São Paulo, v. 23, n. 4, p. 487-495. http://dx.doi.org/10.1590/S010040422000000400011

OLIVEIRA, F.J.S; JUCÁ, J.F.T. (2004) Acúmulo de metais pesados e capacidade de impermeabilização do solo imediatamente abaixo de uma célula de um aterro de resíduos sólidos. Engenharia Sanitária e Ambiental, Rio de Janeiro, v. 9, n. 3, p. 211-217. http://dx.doi. org/10.1590/S1413-41522004000300007

PAÇO DO LUMIAR. (2006) Plano diretor de Paço do Lumiar. Paço do Lumiar: Prefeitura de Paço do Lumiar.

PARANHOS, R. (1996) Alguns métodos para análise da água. Rio de Janeiro: UFRJ.

PEREIRA, L.; SANTIAGO, M.M.F.; MENDONÇA, L.A.R.; FRISCHKORN, H.; LIMA, J.O.G.; MENDES FILHO, J. (2004) Medidas hidroquímicas e isotópicas em águas subterrâneas que abastecem o município de São Luis - Maranhão. Águas Subterrâneas, São Paulo, v. 18, p. 103-119. https://doi.org/10.14295/ras.v18i1.1337

PINTO-FILHO, J.L. de O.; SOUZA, M.J.J.B.; SANTOS, E.G.; GÊ, D.R.F.; CEZAR FILHO, P. (2012) Monitoramento dos teores totais e disponíveis de metais pesados no lixão do município de Apodi-RN. Revista Verde de Agroecologia e Desenvolvimento Sustentável, Mossoró, v. 7, n. 1, p. 141-147.

POMEROY, R.; KIRSCHMAN, H.D. (1945) Determination of dissolved oxygen; proposed modification of the Winkler method. Industrial
Engineering Chemistry and Analytical Edition, v. 17, p. 715-716 https://doi.org/10.1021/i560147a013

RIBEIRO, D.V.; MORELLI, M.R. (2009) Resíduos sólidos: problema ou oportunidade? Rio de Janeiro: Interciência.

SABBAG,S.K.(2013) Orientaçõestécnicas paracoleta, acondicionamento e transporte de amostras de solo. Brasília: Ministério da Saúde.

SAS INSTITUTE INC. (1995) JMP Statitics and Grafics Guide, Version 3.2.6. Computer software and manual. North Carolina: SAS Institute.

SILVA, N.; JUNQUEIRA, V.C.A.; SILVEIRA, N.F.A.; TANIWAKI, M.H.; GOMES, R.A.R.; OKAZAKI, M.M. (2005) Manual de métodos de análise microbiológica da água. São Paulo: Livraria Varela.

SISINNO, C.L.S.; MOREIRA, J.C. (1996) Avaliação da contaminação e poluição ambiental na área de influência do aterro controlado do Morro do Céu, Niterói, Brasil. Cadernos de Saúde Pública, v. 12, p. 515-523. http://dx.doi.org/10.1590/ S0102-311X1996000400010

SISTEMA NACIONAL DE INFORMAÇÕES SOBRE SANEAMENTO (SNIS). (2006) Série Histórica 6: perfil do órgão gestor municipal e perfil das unidades de processamento, 2006. Brasília: SNIS. Disponível em: <http://snis.gov.br/diagnostico-residuos-solidos/ diagnostico-rs-2006>. Acesso em: 15 dez. 2012.

SOUSA, S. (2000) Sistema Aquífero da Ilha do Maranhão. In: CONGRESSO MUNDIAL INTEGRADO DE ÁGUAS SUBTERRÂNEAS, 1., 2000, Fortaleza. Anais... Fortaleza: ABAS.

UNITED STATES ENVIRONMENTAL PROTECTION AGENCY (USEPA). (1989) Soil sampling quality assurance user's guide - EPA 600/8-89/046. Las Vegas: Environmental Monitoring Systems Laboratory.

(1991) Description and Sampling of Contaminated Soils A field pocket guide - EPA 625/12-91/002. Cincinnati: Center for Environmental Research Information.

VAN RAIJ, B.; ANDRADE, J.C.; CANTARELLA, H.; QUAGGIO, J.A. (2001) Análise química para avaliação da fertilidade de solos tropicais. Campinas: Instituto Agronômico. 